\title{
Short communication: Teat wall diameter and teat tissue thickness in dairy cows are affected by intramammary pressure and by the mechanical forces of machine milking
}

\author{
Marina Odorcic, ${ }^{1 *}$ Ulrich Blau, ${ }^{1 *}$ Jenny Löfstrand, ${ }^{2}$ and Rupert M. Bruckmaier ${ }^{1} \dagger$ ( \\ ${ }^{1}$ Veterinary Physiology, Vetsuisse Faculty, University of Bern, Switzerland 3012 \\ ${ }^{2}$ Swedish University of Agricultural Sciences, Uppsala 75007, Sweden
}

\begin{abstract}
The objective of this study was to validate and apply 2 different methods to record changes in teat tissue related to machine milking. Teat wall diameter was measured via B-mode ultrasound cross sectioning with a $7.5-\mathrm{MHz}$ linear probe. Teat tissue thickness was measured using a cutimeter (spring-loaded caliper, spring constant $6.5 \mathrm{~N} / \mathrm{cm}, 0.5 \mathrm{~N}$ at closed jaws). Both methods were applied at the teat barrel, $2 \mathrm{~cm}$ above the teat tip. In experiment 1, 24 teats from freshly slaughtered cows were used to perform ultrasound imaging (12 teats) or cutimeter measurements (12 teats) while the teat cisterns were filled with water to increase the intracisternal pressure from 0 to $30 \mathrm{kPa}$ in steps of $1 \mathrm{kPa}$. Teat tissue thickness did not change at an intracisternal pressure from 0 to $10 \mathrm{kPa}$ but increased with intracisternal pressure at levels $>10 \mathrm{kPa}$. In contrast, teat wall diameter decreased with intracisternal pressure between 0 and $7 \mathrm{kPa}$ but did not significantly change at a pressure $\geq 7 \mathrm{kPa}$ up to $30 \mathrm{kPa}$. Significant Pearson correlation coefficients between intracisternal pressure and teat wall diameter were observed from 0 to $7 \mathrm{kPa}(\mathrm{r}=-0.38)$, and between intracisternal pressure and teat tissue thickness from 10 to $30 \mathrm{kPa}$ $(\mathrm{r}=0.45)$. In experiment 2 , ultrasound and cutimeter measurements were performed in 12 lactating Holstein cows. Measurements before and during milking, immediately after cluster removal, with normal milking or with a 5-min overmilking, were performed and continued at 5-min intervals for $60 \mathrm{~min}$ and at $10-\mathrm{min}$ intervals until $120 \mathrm{~min}$. Additionally, with the 5-min overmilking treatment, measurements were continued at 60 -min intervals up to $10 \mathrm{~h}$ after milking. Teat wall diameter decreased in response to milk ejection, followed by a continuous increase during the course of
\end{abstract}

Received March 4, 2019.

Accepted August 8, 2019.

*These authors contributed equally to this work.

†Corresponding author: rupert.bruckmaier@vetsuisse.unibe.ch milking, with highest values after 5 min overmilking. Teat tissue thickness did not change during milking but was significantly increased after overmilking. Teat wall diameter and teat tissue thickness recovered to premilking levels within 35 min after normal milking and within 60 min after overmilking. Until $10 \mathrm{~h}$ after overmilking, the teat wall diameter decreased steadily, whereas teat tissue thickness was unfluctuating. In the physiologically relevant range of intramammary pressure, ultrasound measurements of the teat wall were affected by both intramammary pressure and mechanical forces, whereas cutimeter measurements were not affected by the intramammary pressure.

Key words: cow, teat tissue thickness, teat wall diameter, ultrasound, cutimeter

\section{Short Communication}

Machine milking with the commonly used 2-chamber teat cups is characterized by continuous vacuum application on the teat throughout milking. A mechanical effect of the vacuum and the pressure of the closed teat cup liner cannot be avoided. This effect can cause short- and long-term changes to teat tissue, such as teat-end congestion and hyperkeratosis. Related changes to the teat tip are mostly analyzed by visual scoring (Neijenhuis et al., 2001a). These changes to the teat tissue are supposed to increase susceptibility to new intramammary infection and should therefore be minimized (Neijenhuis et al., 2001b; Breen et al., 2009; Mein, 2012). Short-term effects such as increased teat wall diameter or teat tissue thickness are believed to be caused by intravascular and extravascular fluid accumulation (Hamann and Mein, 1990). These tissue changes are mostly reversible between 2 consecutive milkings, but they can be indicators of inadequate milking machine settings (Hamann et al., 1993; Hillerton et al., 2002; Besier and Bruckmaier, 2016) and hence may be harbingers of the aforementioned long-term changes. The effects of certain machine settings can disable the complete closure of the teat canal, allowing for bac- 
terial penetration. Zecconi et al. (1992) observed an association between increased teat tissue thickness and higher microbial load in the teat canal. Consequently, higher teat canal colonization is associated with the frequency of hyperkeratosis (Paduch et al., 2012). Short-term changes can be analyzed by instruments such as spring-loaded calipers (cutimeter; Hamann and Mein 1990; Hamann et al., 1993) or B-mode ultrasound cross sectioning of the teat (Bruckmaier and Blum, 1992; Weiss et al., 2004; Wieland et al., 2019). The present study was designed to estimate the shortterm effects of milking, and time needed for tissue to recover from one milking to the following, by using 2 different methods. To our knowledge, few studies have investigated the changes of the teat during the entire interval between 2 milkings in dairy cows (Neijenhuis et al., 2001b; Melvin et al., 2019; Wieland et al., 2019), and none examined different methodologies during the entire interval. Furthermore, we hypothesized that the changes of intramammary pressure (IMP) during the course of milking and congestion of tissue caused by mechanical effects could interfere with the parameters of teats measured via ultrasound and cutimeter. Because ultrasound allows imaging the teat without an effect on the tissue, whereas the cutimeter compresses the tissue with spring-loaded jaws, it is likely that the effects of IMP and congestion on the results of the measurements differ between the two methods. The objective of the study was to quantify the effect of IMP in the physiological $(<10 \mathrm{kPa}$; Wellnitz et al., 1999) and supraphysiological range, and of the mechanical forces of machine milking, including overmilking, on the teat wall diameter measured via ultrasound and teat tissue thickness measured by cutimeter.

For B-mode ultrasound imaging, a Draminski 4 Vet diagnostic ultrasound scanner (Draminski S. A., Olsztyn, Poland) connected to a linear array $7.5-\mathrm{MHz}$ probe was used. For scanning, the teat was immersed in a plastic cup filled with hand-warm water, and the probe was held on the outside of the cup coated with contact gel. Ultrasound teat and udder scanning in water bath prevented deformation of the tissue (Bruckmaier and Blum, 1992; Weiss et al., 2004; Ambord and Bruckmaier, 2010). Cross sectional images at $2 \mathrm{~cm}$ above the teat tip were used for measurement of teat wall diameter by the integrated software of the ultrasound scanner.

Measurements with spring-loaded caliper (cutimeter; spring constant $6.5 \mathrm{~N} / \mathrm{cm}, 0.5 \mathrm{~N}$ at closed jaws) for determining teat tissue thickness were performed essentially as described by Hamann et al. (1988). However, to ensure a measurement at the level of the teat barrel corresponding to the ultrasound measurement, the center of the jaws was placed $2 \mathrm{~cm}$ above the teat end. The jaws surrounded the teat barrel and were slowly and gently closed until the spring pressure was fully applied on the tissue. Cutimeter measurements were always performed after ultrasonography, to exclude a carryover effect of spring pressure on the ultrasound image.

Experiment 1 used 24 teats from Holstein cows slaughtered within $36 \mathrm{~h}$ before the experiment. The teats were removed from the slaughtered udder $2 \mathrm{~cm}$ proximal to the teat basis. Twelve teats each were used to record pressure-dependent changes of teat wall diameter via B-mode ultrasound or teat tissue thickness measured via cutimeter, respectively. Before the start of the experiment, teat length without water in the teat lumen ranged from 31 to $55 \mathrm{~mm}$, and teat diameter was between 21 and $31 \mathrm{~mm}$. The teat canal was closed with a Genesis Teat Dilator (Henry Schein, Lyssach, Switzerland). From the proximal side of the teat, a solid plastic tube was inserted into the teat cistern and fixed by a string from the outside. The free end of the plastic tube was connected to a silicon tube filled with water. The base of the teat was set as zero point for the pressure. Via a water column, the water pressure inside the teat was increased from 0 to $30 \mathrm{kPa}$ in steps of $1 \mathrm{kPa}$.

Experiment 2 used 12 Holstein dairy cows; 3 cows were in their first, 4 in their second, and 6 in their third to eighth lactation, respectively. Cows were between 123 and 384 DIM and produced between 17 and $28 \mathrm{~kg}$ milk per day. All cows were free of clinical mastitis, and foremilk SCC ranged between 65,000 and 150,000 cells/ $\mathrm{mL}$ in all quarters. During the experimental period, the cows were kept in a stanchion barn. Cows were milked twice daily, at 0545 (13 h after previous milking) and at 1645 (11 h after previous milking). Milking was performed with a standard bucket milking unit (Cluster Uniflow 3 SS light; SAC, Kolding, Denmark) with standard liners (Uniflex, product no. 252.15.022; $\mathrm{SAC}$ ). The system vacuum was set at $42 \mathrm{kPa}$, and pulsation rate and pulsation ratio were 60 pulses $/ \mathrm{min}$ and 60:40, respectively. Machine milking and experimental measurements were performed by the same person. The premilking udder preparation (cleaning with a disinfectant tissue, forestripping, and manual teat stimulation) lasted for $1 \mathrm{~min}$. Two treatments were performed, and all 12 cows were used in both treatments in a random crossover between treatments 1 and 2 , and between the individual measurement time points during milking. In treatment 1 , the cluster was manually detached at an approximate milk flow value of $0.2 \mathrm{~kg} / \mathrm{min}$. In treatment 2, cows were overmilked (milk flow $<0.2 \mathrm{~kg} / \mathrm{min}$ ) for 5 min. During milking, teat wall diameter and teat tissue thickness were measured before milk ejection, after milk ejection, 2 min after milking, at the end of plateau milk flow, and after cluster removal either at a milk flow of $200 \mathrm{~g} / \mathrm{min}$ (treatment 1) or after $5 \mathrm{~min}$ 
overmilking (treatment 2). Each of the first 5 measurements during milking was performed twice, once at a morning and once at an evening milking, and only 1 set of ultrasound and cutimeter measurements was performed at an individual milking, to prevent carryover effects of the transient cluster removal and of the ultrasound and cutimeter measurements on the further course of milking. All measurements were carried out on the left front teats of each udder. After milking, measurements were obtained repeatedly at 5-min intervals up to $60 \mathrm{~min}$ and at 10-min intervals until $120 \mathrm{~min}$ in both treatments 1 and 2. In treatment 2, measurements were continued hourly until $10 \mathrm{~h}$ after milking.

For data evaluation we used SAS software (release 9.4; SAS Institute Inc., Cary, NC). To evaluate the data obtained in experiment 1,2 models were designed using MIXED procedures of SAS to test the fixed effect of pressure level (0 to $30 \mathrm{kPa}$ ) on teat wall diameter and teat tissue thickness. Dunnett's test was used to test the differences between measurements at all investigated pressure levels relative to the baseline value at $0 \mathrm{kPa}$ for significance $(P<0.05)$. Teat was included as a repeated subject in the models. Compound symmetry covariance structure was used based on the lowest Akaike's information criterion for both models. Pearson correlation coefficients were calculated using the CORR procedure between teat wall diameter and pressure level in the ranges of 0 to $7 \mathrm{kPa}$ and 7 to 30 $\mathrm{kPa}$, and teat tissue thickness and pressure level in the 0 to 10 and 10 to $30 \mathrm{kPa}$ ranges.

In experiment 2, the MIXED procedure of SAS was used to test for significance in the outcome variables of teat wall diameter (ultrasound) and teat tissue thickness (cutimeter) in 6 models. In models 1 and 2, time points (before milk ejection, after milk ejection, 2 min after milking, at the end of plateau milk flow, after cluster removal, and after milking with 5 min overmilking) were stated as fixed effects. Dunnett's test was used to test the difference between the means of the baseline value (before milk ejection) and measurements during and after milking for significance $(P<0.05)$. Models 3 and 4 observed changes in outcome variables after normal milking and overmilking treatment until $120 \mathrm{~min}$ after milking. Dunnett's test was used to test the difference between the various time points and the 5-min overmilking time point for significance $(P<0.05)$. Treatment and time were stated as fixed effects. Models 5 and 6 were used to assess changes in the outcome variables until $10 \mathrm{~h}$ after overmilking treatment. Time was stated as a fixed effect. Dunnett's test was used to test the differences between the values obtained at 2 $\mathrm{h}$ and those recorded at later time points (4 to $10 \mathrm{~h}$ ). All models included cow as a repeated subject. Based on the lowest Akaike's information criterion, compound symmetry covariance structure was used in all models.

The REG procedure of SAS was used to estimate the time needed for the teat to reach the closest values to those recorded before milking. We investigated the first $60 \mathrm{~min}$ of the total $120 \mathrm{~min}$ and calculated linear regression in intervals of 5 min until optimal goodness of fit was reached. Nonsignificant effects were excluded if $P \geq 0.05$.

In experiment 1 , results obtained by the CORR procedure of SAS showed that teat wall diameter measured via ultrasound (Figure 1A) decreased with increasing pressure in the range of 0 to $7 \mathrm{kPa}:(\mathrm{r}=-0.38, P=$ $0.0005)$ but showed no further change at intracisternal pressures of 7 to $30 \mathrm{kPa}(\mathrm{r}=-0.02, P=0.72)$. With the cutimeter method, no effect on teat tissue thickness was observed below $10 \mathrm{kPa}(\mathrm{r}=0.02, P=0.87)$. Conversely, correlation between pressure and teat tissue thickness was significant in the 10 to $30 \mathrm{kPa}$ range $(\mathrm{r}=0.45, P=0.0001)$. After reaching $26 \mathrm{kPa}$, teat tissue thickness did not increase further, indicating a maximum of elastic stretch of the teat (Figure 1B). Results demonstrated that ultrasound measurements of the teat wall diameter were affected only by intracisternal pressure in the physiologically relevant range, which has previously been shown not to exceed $7 \mathrm{kPa}$ in dairy cows (Wellnitz et al., 1999). Conversely, cutimeter measurements (Figure 1B) were not influenced by intracisternal pressure throughout the range of a physiologically relevant IMP (Wellnitz et al., 1999), but measurements were affected in the supraphysiological range beyond $10 \mathrm{kPa}$. Because degree of udder filling determines IMP in the teat (Mayer et al., 1991; Bruckmaier and Hilger, 2001), it appears likely that the amount of milk in the teat also affected the teat wall diameter in vivo in experiment 2 , which should not be the case for teat tissue thickness measured by cutimeter. Results of measurements during milking in experiment 2 are shown in Figure 2A and B. Teat wall diameter, as measured via ultrasound, decreased during premilking udder preparation - that is, in response to milk ejection $(P=0.0112)$. After cluster attachment, teat wall diameter increased gradually until the end of milking and cluster removal $(P<0.0001)$ and continued to increase when 5-min overmilking treatment was applied $(P<$ $0.0001)$. Results of ultrasound measurement of the teat wall diameter showed that the method was affected with the interaction of endogenous and exogenous factors; different levels of IMP caused immediate changes even in response to milk ejection (Bruckmaier and Hilger, 2001) and through udder emptying, hence decreasing IMP during the course of milking. However, the mechanical forces of the milking machine also contributed 

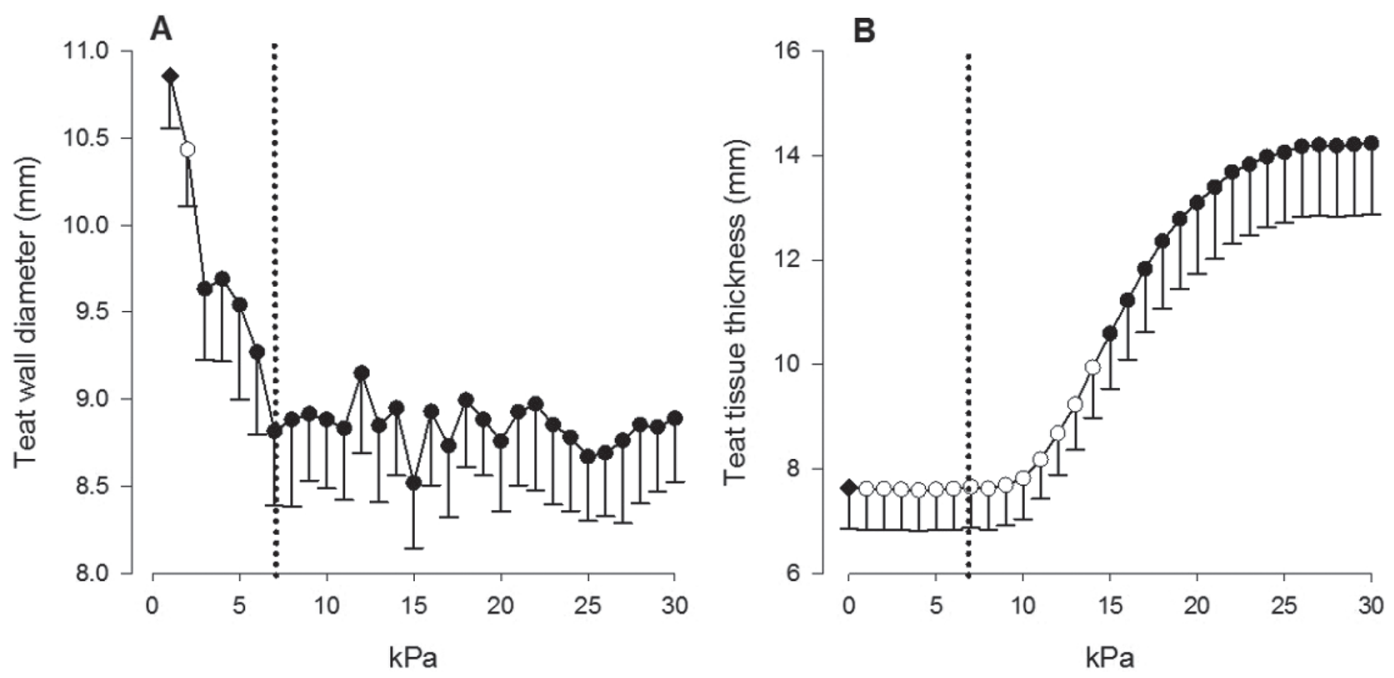

Figure 1. Effects of intracisternal pressure on ex vivo teats; means \pm SEM. (A) Teat wall diameter, determined via ultrasound. (B) Teat tissue thickness, measured by cutimeter. Dotted vertical lines in each panel $(\ldots)=$ upper limit of physiological range $(7 \mathrm{kPa})$; solid diamond $(\bullet)$ = baseline value $(0 \mathrm{kPa})$; empty $\operatorname{dots}(O)=$ not significant; solid dots $(\bullet)=$ significantly different from the baseline value at $0 \mathrm{kPa}$.

to the increase in teat wall diameter, as most obviously demonstrated by overmilking (Figure 2A). Larger teat wall diameters after overmilking are in agreement with the findings of Paulrud et al. (2005) and could be a result of accumulation of extravascular fluid (Hamann and Mein, 1990). This accumulation occurs through the effect of the vacuum on the teat, or the pressure of the closed liner on the teat during milking. A potential consequence of this prolonged effect is congestion of the teat tip or base due to an obstruction in venous return. As shown in Figure 2B, teat tissue thickness measured by cutimeter was only significantly increased after over- milking compared with thickness before milk ejection $(P<0.0001)$. In accordance with the measurements obtained with cutimeter, Isaksson and Lind (1992) did not observe a large difference in thickening of the tissue when comparing measurements before and immediately after milking. In the present study, this method detected obviously the fluid accumulation in the tissue caused by a prolonged action and hence increased mechanical impact of the milking machine when all milk was already removed. This effect has been previously reported by Hamann and Mein (1990). Results of regression models designed to estimate time of tissue
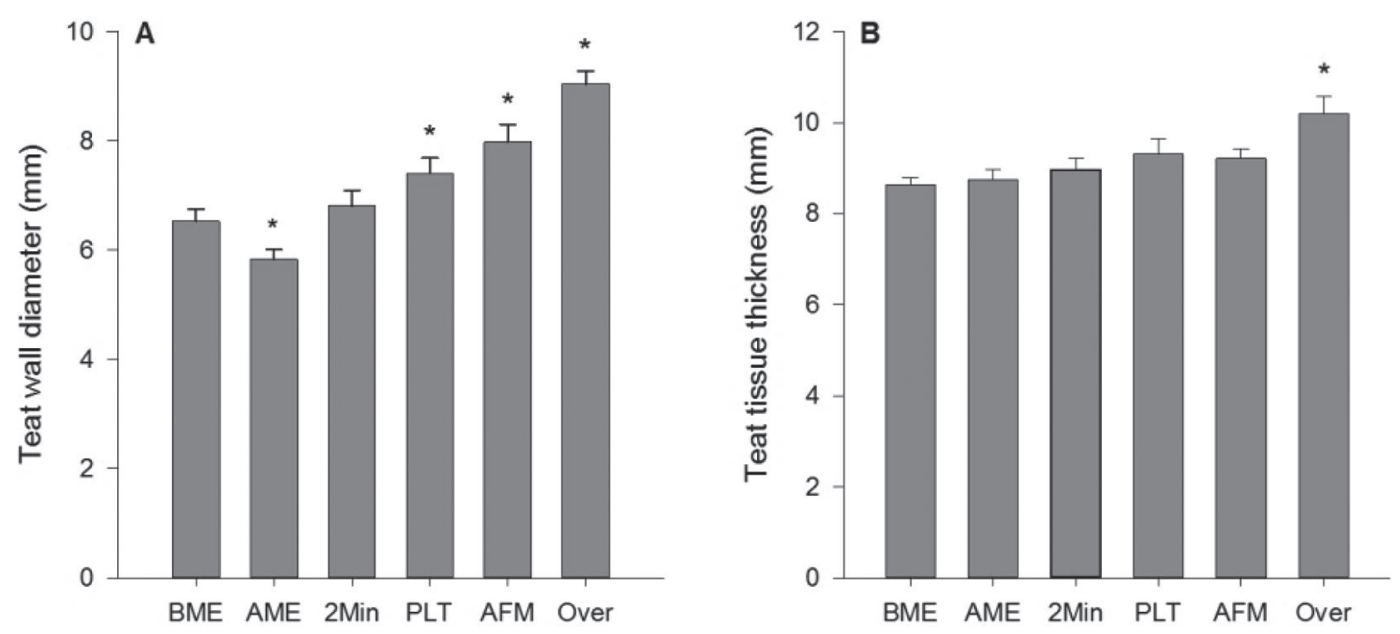

Figure 2. Measurements (means $\pm \mathrm{SEM}$ ) taken before milk ejection (BME), after milk ejection (AME), 2 min into milking (2Min), at the end of plateau milk flow (PLT), immediately after milking with normal milking time (AFM), and after milking with 5 min overmilking (Over). (A) Teat wall diameter, determined via ultrasound. (B) Teat tissue thickness, measured by cutimeter. ${ }^{*}$ indicates mean significantly different from BME baseline. 

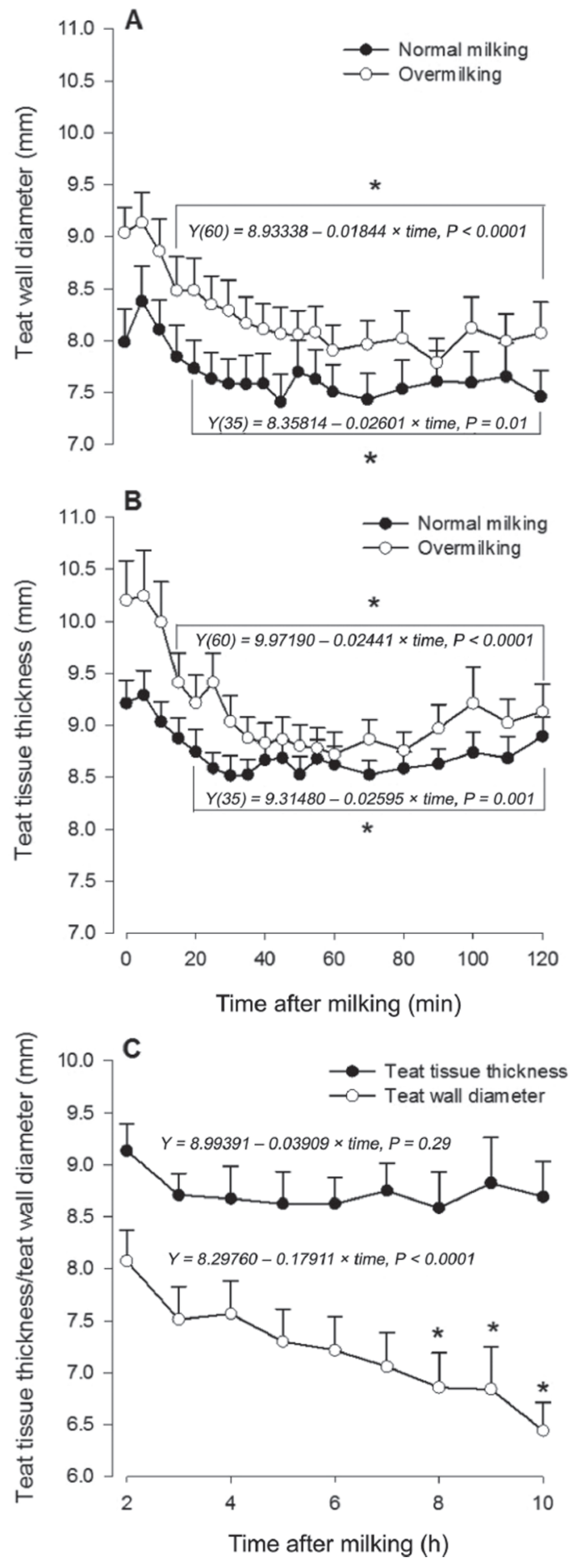

Figure 3. Teat recovery: (A, B) measurements (means \pm SEM) 0 to 120 min after milking for different treatments: normal milking $(\mathbf{O})$ or 5 -min overmilking $(\bigcirc)$. ${ }^{*}$ indicates mean significantly different from the 5-min baseline for normal milking and overmilking. Equations are best-fit linear regression lines (intercept and slope). (A, B) Best fit was reached from 5 to 35 min after normal milkings, and from 5 to 60 min after overmilking. (C) Measurements (means \pm SEM) and regression lines from 2 to $10 \mathrm{~h}$ after 5 -min overmilking; $*$ indicates mean significantly different from the 2 -h baseline. Teat wall diameter was determined via ultrasound and teat tissue thickness was measured by cutimeter. recovery to premilking levels (Figure $3 \mathrm{~A}, \mathrm{~B}$ ) showed that the teat wall diameter and teat tissue thickness recovered within 35 min with normal milking, whereas, after 5 min overmilking, recovery was prolonged to 60 min. Further measurements performed in the treatment until $10 \mathrm{~h}$ after milking with 5 min overmilking (Figure 3C) showed a continued decrease of the teat wall diameter $(P<0.0001)$ with no significant decrease in tissue thickness $(P=0.98)$. Most likely, again, the effect of increasing IMP during the interval between milkings caused the shrinking of the teat wall diameter as determined by ultrasound, whereas the teat tissue thickness measured by cutimeter remained unchanged after recovery from the previous milking. This observation confirms that the cutimeter measurement is independent of IMP in a physiological range. Other groups interpreted a continued decrease of teat wall diameter measured via ultrasound as prolonged recovery time after milking (Martin et al., 2018; Strapák et al., 2018). This hypothesis was not confirmed by our cutimeter measurements. When compared, the ultrasound and the cutimeter show that both methods are suitable for detection of short-term teat changes (Neijenhuis et al., 2001a). However, based on the findings of the present study, teat tissue thickness measured by cutimeter is independent of IMP and is therefore a reliable trait to reflect fluid accumulation in the tissue. We consider this method as most suitable to record the effect of machine milking on the teat tissue, as well as tissue recovery after milking. The ultrasound method may be advantageous to noninvasively record short-term changes of IMP in the udder, as to record occurrence of milk ejection in response to teat stimulation.

\section{REFERENCES}

Ambord, S., and R. M. Bruckmaier. 2010. Milk flow-dependent vacuum loss in high-line milking systems: Effects on milking characteristics and teat tissue condition. J. Dairy Sci. 93:3588-3594. https: //doi.org/10.3168/jds.2010-3059.

Besier, J., and R. M. Bruckmaier. 2016. Vacuum levels and milk-flowdependent vacuum drops affect machine milking performance and teat condition in dairy cows. J. Dairy Sci. 99:3096-3102. https:// doi.org/10.3168/jds.2015-10340.

Breen, J. E., M. J. Green, and A. J. Bradley. 2009. Quarter and cow risk factors associated with the occurrence of clinical mastitis in dairy cows in the United Kingdom. J. Dairy Sci. 92:2551-2561. https://doi.org/10.3168/jds.2008-1369.

Bruckmaier, R. M., and J. W. Blum. 1992. B-mode ultrasonography of mammary glands of cows, goats and sheep during $\alpha$ - and $\beta$-adrenergic agonist and oxytocin administration. J. Dairy Res. 59:151-159. https://doi.org/10.1017/S0022029900030399.

Bruckmaier, R. M., and M. Hilger. 2001. Milk ejection in dairy cows at different degrees of udder filling. J. Dairy Res. 68:369-376. https:/ /doi.org/10.1017/S0022029901005015.

Hamann, J., and G. A. Mein. 1990. Measurement of machine-induced changes in thickness of the bovine teat. J. Dairy Res. 57:495-505. https://doi.org/10.1017/S002202990002954X. 
Hamann, J., G. A. Mein, and S. Wetzel. 1993. Teat tissue reactions to milking: Effects of vacuum level. J. Dairy Sci. 76:1040-1046. https: //doi.org/10.3168/jds.S0022-0302(93)77432-9.

Hamann, J., B. Nipp, and G. A. Mein. 1988. Responses of the bovine teat to machine milking: Measurements of changes in thickness of the bovine teat. J. Dairy Res. 55:331-338. https://doi.org/10 $.1017 / \mathrm{s} 0022029900031800$.

Hillerton, J. E., J. W. Pankey, and P. Pankey. 2002. Effect of overmilking on teat condition. J. Dairy Res. 69:81-84. https://doi.org/ $10.1017 /$ S0022029901005386.

Isaksson, A., and O. Lind. 1992. Teat reactions in cows associated with machine milking. Zentralbl. Veterinarmed. A 39:282-288. https:// doi.org/10.1111/j.1439-0442.1992.tb00184.x.

Martin, L. M., C. Stöcker, H. Sauerwein, W. Büscher, and U. Müller. 2018. Evaluation of inner teat morphology by using high-resolution ultrasound: Changes due to milking and establishment of measurement traits of the distal teat canal. J. Dairy Sci. 101:8417-8428. https://doi.org/10.3168/jds.2018-14500.

Mayer, H., R. Bruckmaier, and D. Schams. 1991. Lactational changes in oxytocin release, intramammary pressure and milking characteristics in dairy cows. J. Dairy Res. 58:159-169. https://doi.org/ $10.1017 /$ S0022029900029708.

Mein, G. A. 2012. The role of the milking machine in mastitis control. Vet. Clin. North Am. Food Anim. Pract. 28:307-320. https://doi .org/10.1016/j.cvfa.2012.03.004.

Melvin, J. M., W. Heuwieser, P. D. Virkler, D. V. Nydam, and M. Wieland. 2019. Machine milking-induced changes in teat canal dimensions as assessed by ultrasonography. J. Dairy Sci. 102:26572669. https://doi.org/10.3168/jds.2018-14968.

Neijenhuis, F., H. W. Barkema, H. Hogeveen, and J. P. T. M. Noordhuizen. 2001a. Relationship between teat-end callosity and occurrence of clinical mastitis. J. Dairy Sci. 84:2664-2672. https://doi .org/10.3168/jds.S0022-0302(01)74720-0.

Neijenhuis, F., G. H. Klungel, and H. Hogeveen. 2001b. Recovery of cow teats after milking as determined by ultrasonographic scanning. J. Dairy Sci. 84:2599-2606. https://doi.org/10.3168/jds .S0022-0302(01)74714-5.
Paduch, J. H., E. Mohr, and V. Krömker. 2012. The association between teat end hyperkeratosis and teat canal microbial load in lactating dairy cattle. Vet. Microbiol. 158:353-359. https://doi.org/ 10.1016/j.vetmic.2012.02.032

Paulrud, C. O., S. Clausen, P. E. Andersen, and M. D. Rasmussen. 2005. Infrared thermography and ultrasonography to indirectly monitor the influence of liner type and overmilking on teat tissue recovery. Acta Vet. Scand. 46:137-147. https://doi.org/10.1186/ 1751-0147-46-137.

Strapák, P., I. Szencziová, and E. Strapáková. 2018. Measurement of teat structures of dairy cow through ultrasonography and examination of morphological changes in teats caused by machine milking. Vet. IR Zootech. 76:62-69.

Weiss, D., M. Weinfurtner, and R. M. Bruckmaier. 2004. Teat anatomy and its relationship with quarter and udder milk flow characteristics in dairy cows. J. Dairy Sci. 87:3280-3289. https://doi.org/ 10.3168/jds.S0022-0302(04)73464-5.

Wellnitz, O., R. M. Bruckmaier, and J. W. Blum. 1999. Milk ejection and milk removal of single quarters in high yielding dairy cows. Milchwissenschaft 54:303-306.

Wieland, M., P. D. Virkler, A. H. Borkowski, N. Älveby, P. Wood, and D. V. Nydam. 2019. An observational study investigating the association of ultrasonographically assessed machine milking-induced changes in teat condition and teat-end shape in dairy cows. Animal 13:341-348. https://doi.org/10.1017/S1751731118001246.

Zecconi, A., V. Bronzo, G. Ruffo, and J. Hamann. 1992. Machineinduced teat tissue reactions and infection risk in a dairy herd free from contagious mastitis pathogens. J. Dairy Res. 59:265-271. https://doi.org/10.1017/S0022029900030545.

\section{ORCIDS}

Rupert M. Bruckmaier ํㅜ https://orcid.org/0000-0002-9374-5890 